\title{
Research on assembly line balancing based on electronic products
}

\author{
Zhao Ling \\ School of Mechanical and Electric Engineering, Soochow University \\ Suzhou, China \\ zhaoling@suda.edu.cn
}

\begin{abstract}
With the upgrade and transformation of our industry, CCFL (Cold Cathode Fluorescent Lamp) is widely used. It features high brightness, high efficiency and low power consumption; can rapid start at low temperature; control color temperature accurately; small in size and light in weight; tolerate high vibration; can easily process to various shapes (straight shape, L-shape, U-shape, toroidal shape, etc.); decorate well. With the maturity of the LCD technology, CCFL has a wide market prospect. The annual growth rate maintained at above $60 \%$ ! Consequently, how to increase production and decrease cost attracts more and more attention.In this paper, based on the Cold Cathode Fluorescent Lamp assembly production line as the research object, the application of industrial engineering methods, through detailed analysis and Research on the workshop layout, logistics control, plant layout, equipment and production line balance, proposed the improvement scheme of new. The production line more balance, improve productivity, and satisfactory results have been obtained.
\end{abstract}

Keywords-Line Balancing ; Cold Cathode Fluorescent Lam ; Process of Production ; Industrial Engineering ; Fixture

\section{INTRODUCTION}

With the increasing application of backlight illumination in laptops used in office, plasma display panels and household appliances such as televisions, digital cameras, cameras, etc., highly luminous Cold Cathode Fluorescent Lamp (CCFL) is born. The diameter of this type of lamps ranges from $1.8 \mathrm{~mm}$ to $3.0 \mathrm{~mm}$. It generally uses tricolor fluorescence powder and metal like $\mathrm{Ni}, \mathrm{Ta}, \mathrm{Zr}$, etc., as its cold cathode. The tube works by forming glow discharge with highly threshold voltage. Statistics show that its recent sales increase $30 \%$ per year. It features high brightness, high efficiency and low power consumption; can rapid start at low temperature; control color temperature accurately; small in size and light in weight; tolerate high vibration; can easily process to various shapes (straight shape, L-shape, U-shape, toroidal shape, etc.); decorate well. With the maturity of the LCD technology, CCFL has a wide market prospect, remaining $60 \%$ growth per year. Presently, Japan is the largest producer of CCFLs occupying about $60 \%$, followed by Taiwan, accounting for $18 \%$ approximately. With the upgrade and transformation of our industry, CCFL is widely used. As a consequence, how to increase production and decrease cost attracts more and more attention.

The productivity is the essential factor for the development and existence of enterprises. To the enterpriseusing assembly line, the situation of the line directly affects the productivity, quality, lead-time, etc., and finally affects the performance and reputation of enterprises. Meanwhile, after entering the mature stage of development, the enterprise will stall relatively, compared with the rapid increasing stage. At that time, various problems ignored during the rising stage will be emerged, such as unsuitable equipment layout and irregular operation, causing problems in the producing system. There are two ways to solve problems completely: first redeploy the layout and second solve it by industrial engineering.

In this paper, a research and improvement of line is made for a certain firm in Suzhou Industrial Park, by spot investigation, constant analysis, summary, adjust and standard process. Furthermore, the optimized assembly line successfully operates in the company. The production level of the company greatly increases after the improvement.

\section{ANALYSIS OF THE PRESENT PROBLEM}

\section{A. The current situation of producing system}

The workshop mainly produces tubes (CCLF) used for display backlight, concerning on assembly with manual labour. It is labor-intensive industry. Now the workshop has 146 workers in two shifts. In order to meet to the month output 300,000, workers need to work overtime 3-5 days. Furthermore, the plan indicates the future output will rise to 50,000 per month. Hence, it is urgent to analyze the current problem, find out the factor affecting the line balance and take improvement, which aims at enhancing productivity and output.

The workshop assembles Cold Cathode Fluorescent Lamp (CCFL). After having a series of assembly processes (two tubes per unit), the finished product can be used in the manufacture of backlight. The present line is manual labour, which means products are passed to the next work station by workers. Workers work 10 hours every day and are in two shifts composed of 74 workers (one current manager). Because the output doesn't reach the requirement, the enterprise takes measure to complete the mission, like work 
overtime, enhance line, increase area, etc., which greatly gains the cost.

\section{B. Analyze the problem}

By the analysis of program, operation and motion during the research and detailed investigation of assembly process, the problem can be figured out.

During the investigation and test, we find that the layout is unreasonable and the logistics is influent; without a standard, the arrangement of materials causes hard posture; the operation motion differs and needs to be improved; fixtures cannot meet the production requirement. For example, the tool used for warming bushing will get uneven heat and affect the quality and efficiency. As shown in Picture 1, in the process of measuring high voltage, the fixture can only install two tubes. Therefore, every time only two tubes can be measured, this affects the efficiency. The information about the SOP of the workshop and the productfinishing situation, especially the standard time, does not match the real data. Besides, we take measures of every process and the result is shown in Table I.

From the table I, the line balance efficiency can be calculated as shown below:

TABLE I PROCESS TIME STATIST ICS

\begin{tabular}{|c|c|c|c|c|}
\hline Process & Content & $\begin{array}{l}\text { No. of } \\
\text { worker }\end{array}$ & $\mathrm{ST} / \mathrm{S}$ & $\mathrm{CT} / \mathrm{S}$ \\
\hline 1 & Cut waste & 1 & 5.3 & 5.3 \\
\hline 2 & $\begin{array}{l}\text { Set O-shaped } \\
\text { ring }\end{array}$ & 5 & 26.62 & 5.32 \\
\hline 3 & $\begin{array}{l}\text { Prepare for } \\
\text { wire and rod }\end{array}$ & 11 & 60.33 & 5.48 \\
\hline 4 & Weld & 12 & 57.73 & 4.81 \\
\hline 5 & $\begin{array}{lr}\text { Clean } & \text { and } \\
\text { check } & \text { solder } \\
\text { joint } & \end{array}$ & 1 & 5.98 & 5.98 \\
\hline 6 & $\begin{array}{l}\text { Warm solder } \\
\text { joint bushing }\end{array}$ & 6 & 27.1 & 4.52 \\
\hline 7 & $\begin{array}{l}\text { Locate lamp- } \\
\text { socket and } \\
\text { adjust O- } \\
\text { shaped ring }\end{array}$ & 6 & 33.12 & 5.52 \\
\hline 8 & $\begin{array}{l}\text { Stock } \\
\text { lampshade }\end{array}$ & 4 & 18.68 & 4.67 \\
\hline 9 & $\begin{array}{l}\text { Tear double- } \\
\text { sided tape } \\
\text { assemble and } \\
\text { arrange wire }\end{array}$ & 10 & 54.51 & 5.45 \\
\hline 10 & $\begin{array}{l}\text { Stick fixed } \\
\text { tape }\end{array}$ & 4 & 20.68 & 5.17 \\
\hline 11 & $\begin{array}{l}\text { Warm big } \\
\text { bushing }\end{array}$ & 7 & 38.47 & 5.5 \\
\hline 12 & $\begin{array}{l}\text { Measure } \\
\text { voltage }\end{array}$ & 3 & 17.65 & 5.88 \\
\hline 13 & FQC & 2 & 15.55 & 7.78 \\
\hline \multirow[t]{2}{*}{14} & Package & 1 & 7.65 & 7.65 \\
\hline & Total & 73 & 388.37 & \\
\hline
\end{tabular}


4) Assemble and arrange wire: By changing the location of fixture and declining the moving distance, it is easier to operate with shorter time.

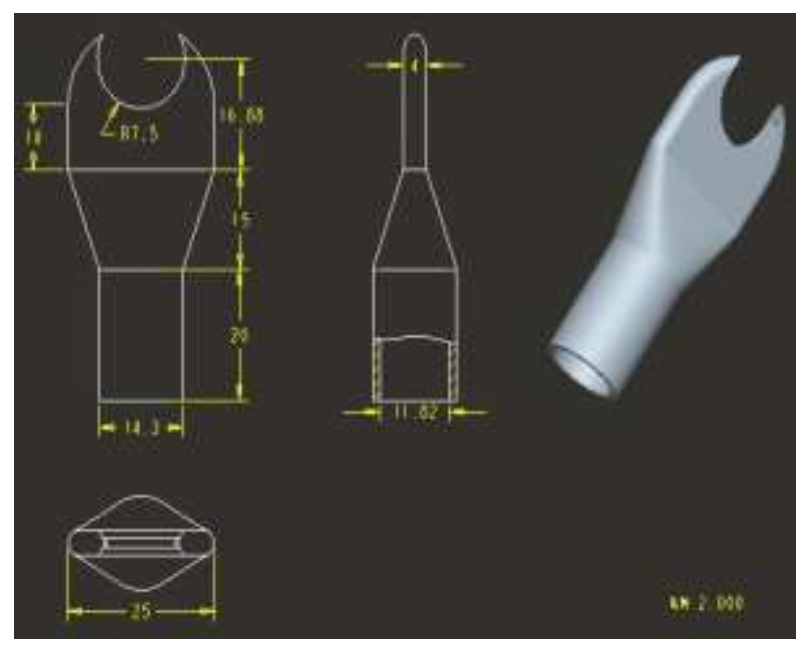

Figure 2. Improved Fixture

5) Combine the voltage measure with FQC: The process of measuring high voltage and FQC is almost the same, except the former has one more measure process than the latter, which means that only pay a little attention to the former one can the latter one be finished. Therefore, these two processes are merged. The total time after combination is $10.02 \mathrm{~s}$, saving $1.53 \mathrm{~s}$.

Redesign the fixture of measuring voltage, which increases the amount of measuring every time.

\section{RESULTS AND ANALYSIS}

\section{A. Improve the line capacity.}

After improving, the line becomes more fluent and the process becomes more reasonable. In addition, the line balance efficiency is highly intensified. The table 2 shows the operation time of every workstation before and after the improvement. The time of line declines to $2.25 \mathrm{~s}$ compared with $7.78 \mathrm{~s}$ before and the line balance efficiency rises from $68.38 \%$ to $84.28 \%$, which means the line capacity gains $15.9 \%$.

The real line balance efficiency of tube group:

$\mathrm{W}=175.36 \div(2.85 \times 73) \times 100 \%=84.28 \%$

The loss rate of line balance $=1-84.28 \%=15.72 \%$

\section{B. Save the human resource and decline the labor cost.}

Improve the line and analyze the qualification of rising productivity. Modify the common understanding of exclusively presuming large output and working overtime.

\section{Improve the "5S" image of workshops.}

The assembly line is tidier and more reasonable, and the environment is better, Safety guaranteed.

\section{THE CONCLUSION}

This article, taking the company as an example, analyzes and improves the production lines. The result can be showed by the increase of $15.90 \%$ in the balance rate. In fact, the methods used are, and can be shared by the other

TABLE II. PROCESS TIME STATISTICS

\begin{tabular}{|c|c|c|c|c|}
\hline Process & Content & $\begin{array}{r}\text { No. of } \\
\text { workers }\end{array}$ & $\mathrm{ST} / \mathrm{S}$ & $\mathrm{CT} / \mathrm{S}$ \\
\hline 1 & Cut waste & 1 & 1.65 & 1.65 \\
\hline 2 & $\begin{array}{l}\text { Set O-shaped } \\
\text { ring }\end{array}$ & 5 & 13.34 & 2.67 \\
\hline 3 & $\begin{array}{r}\text { Prepare for } \\
\text { wire and rod }\end{array}$ & 12 & 34.22 & 2.85 \\
\hline 4 & Weld & 12 & 26.06 & 2.17 \\
\hline 5 & $\begin{array}{c}\text { Clean and } \\
\text { check solder } \\
\text { joint }\end{array}$ & 1 & 2.5 & 2.5 \\
\hline 6 & $\begin{array}{l}\text { Warm solder } \\
\text { joint bushing }\end{array}$ & 6 & 15.32 & 2.55 \\
\hline 7 & $\begin{array}{l}\text { Locate lamp- } \\
\text { socket and } \\
\text { adjust O- } \\
\text { shaped ring }\end{array}$ & 6 & 16.32 & 2.72 \\
\hline 8 & $\begin{array}{c}\text { Stock } \\
\text { lampshade }\end{array}$ & 4 & 7.88 & 1.97 \\
\hline 9 & $\begin{array}{l}\text { Tear double- } \\
\text { sided tape } \\
\text { /assemble and } \\
\text { arrange wire }\end{array}$ & 10 & 21.91 & 2.19 \\
\hline 10 & $\begin{array}{l}\text { Stick fixed } \\
\text { tape }\end{array}$ & 4 & 9.37 & 2.34 \\
\hline 11 & $\begin{array}{l}\text { Warm big } \\
\text { bushing }\end{array}$ & 7 & 14.58 & 2.08 \\
\hline 12 & $\begin{array}{c}\text { Measure } \\
\text { voltagelFQC }\end{array}$ & 4 & 10.05 & 2.51 \\
\hline \multirow[t]{2}{*}{13} & Package & 1 & 2.16 & 2.16 \\
\hline & Total & 73 & 175.36 & \\
\hline
\end{tabular}

kinds of company. The company's improvements achieved good results, but there are also inadequate.

Due to the existence of some factors, which are changing constantly such as the updating of production environment and staffs, the development of proficiency of personnel operation level, and production improvement. It requires the production line can find out problems, and analyze them, finally work out them. Through the development of production line and constantly updating proceed; the production line can meet the demand of new balance in higher level. Production line should be improved constantly when finding out new limits in different environment, by which the enterprise can continuously improve efficiency of production. It's the ultimate target, which an enterprise really works for, and it's also the true meaning of industrial engineering. That the field of industrial engineering improvement activities should be constantly ongoing process. Constantly looking for the best production line. 
Production line optimization and efficiency improvement are common problems in all enterprises. Because of its advantages in improving producing efficiency, such as low investment, quick effectiveness and solving the problem in some degree, the pause after rapid development, industrial engineering is suggested to be wide spread. Especially at this moment that our native enterprises are faced with the trouble of manpower shortage, if enterprises can implement industrial engineering scientifically, the productivity and the market competition can be intensified effectively.

At present, in the face of problems of labor shortage, if domestic companies can applied industrial engineering, enterprises could effectively increase the efficiency and enhance their marketability, through analyzing and improving methods of operation, refining the equipment function, updating equipment and carrying out a series of plan to train employees.

Through the analysis to the above assembly line, we know that the cycle time can affect a lot on the capacity, but we cannot simply take the minimum cycle time as the only goad without noticing the balance rate of the whole assembly line, otherwise it will be very inconvenient to manage the line due to the excessive production procedures. Thus, how to constantly improve the capacity of the production line, how to eliminate the bottleneck and reduce the loss of balance rate are the problems that many companies are facing. Industrial Engineering theory is the best way to improve the production line. In this article, after analyzing and improving the production line, it successfully increases the capacity and eliminating the bottleneck.
It should be noted that the improvement is endless; we should continue find problems, then analyze and improve the problems so that the production line would be upgraded to a new level.

Set the custom satisfactory as goals; continue elevating and upgrading by using the continuous improvement theory are supposed to be one of the very important duty in company's daily life.

\section{REFERENCES}

[1].Information on http://www.chinaie.info/

[2].Shu ping Yi: The Foundation of Basic Industrial Engineering. Beijing: Machine Press, (2006)

[3].Hao Zhao: Production Management. Beijing: Metallurgical Industry Press, 1992, 45-46

[4].Bai Dongzhe. Sheng chan xi tong xian chang gong zuo yan jiu [M]. China Machine Press, 2004: 127-148.

[5].Lin Rongrui. Guan li ji shu [M]. Xiamen University Press, 1999: 347-349.

[6].Junichi Ishiwata, Yin Ichiro Kato. Zui xin xian chang IE guan li [M]. Haitian Press, 2004: 628-638.

[7].Er shi qi: Modern Industrial Engineering and Management Tianjin University Press, (2007)

[8].W M P van der Aalst, K M Van Hee.Business process redesign: A Petri-net-based approach [J].Computers in Industry, 1996,29:15-26

[9].Fred E Meyers. Manufacturing Facilities Design and Material Handling[M] Qinghua University Press(2002)

[10].Junmin Yin: Logistics Engineering [M] Publishing House of Electronics Industry 2013.7 